\title{
Japan ties the industry/university knot
}

[TOKYO] Japan's Ministry of International Trade and Industry (MITI) and the Ministry for Education, Science, Sports and Culture (Monbusho) are considering setting up 'technology liaison offices' to help improve collaboration between universities and industry.

The plan is one of several recommendations in a proposed new bill for promoting industry/university collaboration, which the two ministries announced last week. The liaison offices would either be set up individually at universities, or exist as regional offices that could be accessed by several universities in the area.

In contrast to the United States, there is comparatively little interaction in research and development between universities and industry in Japan. This is particularly true at national universities, where civil service law prevents scientists from being involved in research in industrial laboratories or profitmaking activities. Thus, whereas US universities obtained 1,900 patents in 1994, for example, Japanese universities gained only 130 in the same year, according to MITI.

The proposed bill will allow private companies to fund universities setting up venture businesses, in contrast to the current system, under which funding from companies to private and national universities is restricted to grants, scholarships and donations. Monbusho is also considering modifying the civil service law to enable scientists at national universities to help set up venture companies and to get involved in research in industry.
According to MITI, the liaison offices will assist universities with drawing up research contracts for joint projects with industrial laboratories, and will help companies to set up their own research centres at universities.

MITI's Masahiro Hashimoto is in charge of promoting interaction between industry and universities. He says the new bill, which will be submitted to the next session of the Diet (Japan's parliament) in December, will be a "very positive move".

Some national universities, such as Tokyo University, Tokyo Institute of Technology and Tsukuba University, have already set up liaison offices. But they have sometimes had to appoint postgraduate students as directors of these offices because of the law prohibiting university staff from involvement in profit-making activities.

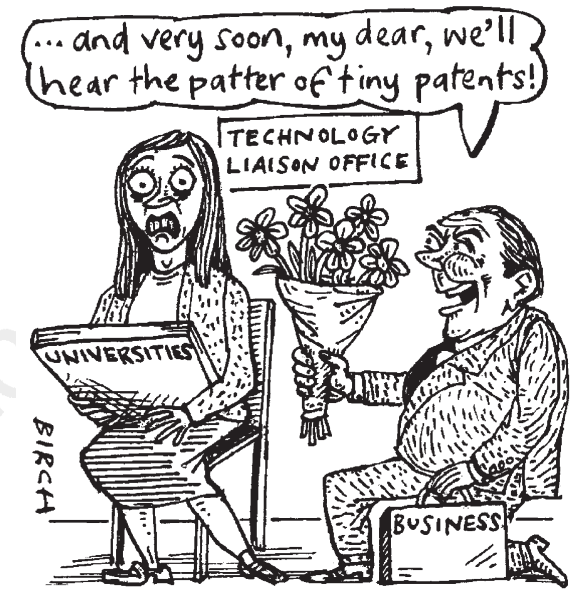

"The technology liaison office can advise scientists on the commercial exploitation of inventions made from their research," says Hashimoto. "The new bill will allow national universities to profit from their inventions whereas any income gained from patents and industrial applications under the current system is collected by central government.'

For industry and universities to collaborate successfully, the universities will have to change their attitude, says Susumu Nishimura, director of the research centre at Banyu Pharmaceuticals in Tsukuba science city. "Researchers at universities must change their perception that industry is just a source of funding. If there is to be 'real' collaboration between universities and industry, they (universities) will need to start implementing 'commercially applicable' research from which industry can benefit."

Nishimura adds that the present environment in Japanese universities will make it difficult for venture businesses to thrive. "There is still a strong feeling that good researchers do not normally get involved in business activities."

"Japanese universities and national research centres are not equipped with adequate measures to protect intellectual property and to advise on appropriate procedures for commercial development of inventions," says Nishimura, "It is quite often the case that researchers miss their chance to obtain patents from their inventions simply due to lack of support in that area."

\section{British study will assess risks of vCJD blood transmission}

[PARIS] The British government last week launched a study into the risk that the agent that causes the new variant of CreutzfeldtJakob disease (vCJD) might be transmitted by blood, and instructed the National Blood Authority to look at ways of reducing the potential risk.

The moves were announced by Frank Dobson, the health secretary, following advice from the government's Spongiform Encephalopathy Advisory Committee (SEAC). The committee says recent research suggests that the pathogenesis of vCJD differs from that of classical CJD in that the causative agent may occur in particular in lymphocytes, and that it would therefore be "logical" to consider removing such cells from blood products.

SEAC pointed out that while it is so far impossible to assess the risk of transmission of vCJD, risk assessments are urgently needed to obtain a clearer picture. Dobson said his department will carry out a full study immediately, and will consider introducing the leukodepletion of blood, depending on the outcome of the study.

Steve Dealler, a bovine spongiform encephalopathy (BSE) researcher at Burnley General Hospital, who has been campaigning vigorously about the potential risks of contaminated blood (see

Transfusion Medicine, 6, 217; 1996), welcomed the government's action, but says that it should have been taken immediately after the risk of BSE passing to humans was acknowledged in March last year.

Dealler and others are sceptical about whether leukodepletion of blood will be sufficient to eliminate all risk, as plasma is likely to be contaminated by leakage from broken cells. The solution would be to screen donors for the disease, he points out, arguing that this makes development of a diagnostic test for vCJD a priority.

Efforts to do so may be helped by the recent discovery of a monoclonal antibody specific for the abnormal version of the prion protein thought to cause the disease (see Nature 390, 74; 1997).

The government "is acting responsibly" in taking a precautionary stance, says Tony Wilson, chief executive officer of the UK Haemophilia Society. But he remains concerned that economic factors may be given excessive weight in the cost-benefit analysis of the safety of blood products. He points out that most UK haemophiliacs are still treated with clotting factors from natural blood, which are inherently more risky than the recombinant alternatives widely used elsewhere, because the natural products are cheaper in Britain.

Meanwhile, the French national bioethics committee last week concluded that while the risk of transmission of vCJD by blood remained "hypothetical", a body should be set up to monitor scientific knowledge of the risk. Dealler adds that the renewed attention on the risk of blood products suggests it is only a matter of time before European countries raise the question of a ban on exports of British blood products.

Declan Butler 